\title{
Determining positions for control locations in environmental studies of estuarine marinas
}

\author{
T. M. Glasby*, A. J. Underwood \\ Centre for Research on Ecological Impacts of Coastal Cities, Marine Ecology Laboratories, A11, University of Sydney, \\ New South Wales 2006, Australia
}

\begin{abstract}
Recruitment and development of subtidal epibiota were sampled using settlement plates to identify appropriate control locations for tests of environmental impacts of estuarine marinas. Sampling was designed to determine how far any effects of marinas may extend and how the position of a location within an estuary may affect the recruitment and development of epibiota. Marinas may have had minor impacts on epibiotic assemblages, but certainly wone that extended further than $1.5 \mathrm{~km}$; hence, locations $1.5 \mathrm{~km}$ from marinas could potentially serve as controls. Assemblages at the inner end of a creek were, however, likely to be very different from those at positions closer to the mouth. Thus, for studies of marinas situated at the ends of creeks, control locations would need to be in corresponding positions in adjacent creeks. Without information of this kind, impacts may be either detected erroneously or masked because inappropriate control locations might be used
\end{abstract}

KEY WORDS: Subtidal organisms Fouling - Recruitment Environmental impact assessment Australia

\section{INTRODUCTION}

One of the most important aspects of any environmental study is the choice of control locations. This will be particularly important for any 'post-impact' study (i.e. when no data have been collected before the disturbance occurred) because an impact will often not be detected if there is great variability among the controls (Peterson 1993, Glasby 1997). This is not to suggest that the only criterion for choosing control locations is that they be similar to each other. Controls must be chosen randomly from a set of locations which are representative of the disturbed location. Thus, we must outline a priori the characteristics of the disturbed location which are important to consider so that a distribution of similar locations (from which controls will be randomly chosen) can be defined. Even though it is not necessary (nor actually possible) for any control locations (even one) to be identical to the disturbed location (Underwood 1994), certain features of both must

•E-mail: tglasby@bio.usyd.edu.au be similar. It is difficult to know which characteristics of a location are the most important to duplicate in controls, but the suggested selection criteria fall into 3 broad categories. Control locations must: (1) be unaffected by the disturbance being investigated, (2) have the same types of habitats as the disturbed location and (3) have physical and morphological characteristics similar to those of the disturbed location (Green 1979, Underwood 1992, 1994, Stewart-Oaten 1996). In some situations, this will mean that the closer the controls are to the disturbed location, the better (provided that they are spatially independent of the disturbance in question). This may not be the case, however, if there is some sort of natural environmental gradient away from the disturbed location. If this occurs, controls may need to be in comparable positions within this type of gradient, even if this means that they must be many kilometres away.

When the spatial extent of a disturbance is not known, sampling can be done using a 'gradient' design (see Bayne et al. 1988, Wiens \& Parker 1995) or at a variety of spatial scales and the data analysed using a nested design (Underwood 1981, 1992, An- 
drew \& Mapstone 1987, Morrisey \& Underwood 1992). A combination of these 2 approaches was used here to estimate the spatial extent of effects of marinas on the recruitment of subtidal epibiota growing on hard substrata. Knowledge of spatial scale would facilitate the choice of control locations for future comparisons. This formed part of a larger study to examine the model that marinas in Sydney, Australia, are having a press (sustained) impact (Bender et al. 1984) on these assemblages of epibiota. The test for a press disturbance having an ongoing effect on organisms involves sampling the development of new assemblages (as described here) which can only be affected by current (or future) disturbances (Glasby \& Underwood 1996).

Almost no work has been done to determine how far the environmental effects of marinas may extend. The little information available concerns the concentration of contaminants (mainly tributyltin, TBT) in the water and sediments around marinas. These studies were not specifically designed to examine how far contaminants may extend from their source, but the results suggest that large concentrations of TBT (sufficient to cause deformities in marine invertebrates) tend to be found within $1 \mathrm{~km}$ of a marina (Batley et al. 1989, Hasan \& Juma 1992, Ko et al. 1995, McGee et al. 1995). For most studies, either information about control locations was not provided, or no control was actually used. Baird et al. (1981) had 1 control approximately $1 \mathrm{~km}$ from the marina that they studied, while Van Dolah et al. (1992) used control sites situated in an adjacent creek, approximately $5 \mathrm{~km}$ from the marina. Given that there is essentially no information about how far ecological effects of marinas may extend (nor about spatial scales of natural variation), it is impossible to predict whether impacts may be small- or large-scale. We investigated the model that marinas have large-scale impacts on sessile epibiota and these impacts extend up to $1.5 \mathrm{~km}$. Thus, it was predicted that if the establishment of subtidal assemblages were sampled in a marina and at a location $1.5 \mathrm{~km}$ away, there would be no differences between the 2 locations. Furthermore, the establishment of assemblages at any locations further than $1.5 \mathrm{~km}$ from a marina should be different from that at the marina. These patterns should be different from any observed among control locations spaced at similar distances.

The marinas examined were located in estuarine creeks. It was also important, therefore, to consider natural differences along the creeks with regard to the positions of control locations. For this, it was necessary to establish whether there was any sort of environmental gradient within the creeks. There is substantial evidence to suggest that a variety of oceanographic, physical and chemical features of an estuary may vary along its length (e.g. Parsons et al. 1990). Salinity, tem- perature, turbidity, dissolved oxygen content, water flow and flushing may all vary considerably within an estuary (Barnes 1984, Cosser 1989, Barnes \& Hughes 1990, Parsons et al. 1990, Le Bris \& Glémarec 1996). A number of these features may alter according to the volume of freshwater entering the estuary (Barnes 1984). Given that the marinas in question were situated at the ends of creeks (see Fig. 1) where freshwater streams discharge, we proposed that a variety of abiotic and biotic features differed between these locations and others closer to the mouths of the creeks and that this differentially affected the establishment of epibiota. We hypothesised that the establishment of subtidal assemblages would differ along a creek and that the greatest difference would be between the mouth and the end of the creek.

The aims of this study, therefore, were to test our hypotheses concerning the spatial extent of the effects of marinas and the prediction that the establishment of subtidal assemblages at the ends of creeks is very different from that closer to the mouths of creeks. It is quite likely that recruitment and/or the effects of marinas may vary over relatively short time periods and that any effects on epibiota may be expressed at different stages of the development of assemblages. It was therefore decided that this study would be done twice during one summer and that different developmental stages would be examined.

\section{MATERIALS AND METHODS}

Sandstone settlement plates $(15 \times 15 \mathrm{~cm})$ were used to study the establishment of subtidal assemblages. All the plates had been used previously (i.e. been under water for at least $1 \mathrm{mo}$ ) and had been immersed in $20 \%$ $\mathrm{HCl}$, scrubbed clean, soaked in fresh water and dried. Plates were attached to aluminium angle beams $\left(90^{\circ}\right.$ angle bracket, $32 \mathrm{~mm}$ side width). The beams were attached horizontally to the rocky reef, parallel to the shore, using 2 self-tapping stainless steel screws and rawl plugs that were drilled into the rock. Plates were attached vertically to the beams via a PVC bracket which was placed over and bolted onto 2 stainless steel threaded rods drilled through the side of the aluminium angle that was not attached to the substratum (Glasby 1998). The plates stood vertically in the water column at a depth of $1.5 \mathrm{~m}$ below mean low water springs and faced away from the shore

Plates were deployed at 9 locations, 3 in each of 3 creeks in Ku-ring-gai Chase National Park, Sydney (Fig. 1). This area is popular for recreational boating, but there are few other anthropogenic disturbances because locations are in a National Park. The creeks are formed by deeply incised sandstone valleys and 
reach a maximum depth of $-25 \mathrm{~m}$. Two creeks had marinas situated near the end. Halvorsen Marina is in Cowan Creek and Akuna Bay Marina is in Coal \& Candle Creek (Fig. 1). These marinas have been operating for more than 20 yr (Halvorsen's for $50 \mathrm{yr}$ ) and each supports upwards of 200 boats. At Halvorsen's, most boats are on swing moorings, whereas all boats at Akuna Bay Marina are in berths. Both marinas sell fuel and have slipways for repairing boats and applying antifouling paints. Smiths Creek was chosen as a control because it does not contain a marina, it is in between the other creeks and is ostensibly very similar to them, i.e. all 3 creeks are surrounded by National Park, face a similar direction, are steep-sided and have a freshwater stream running into the end of them. Furthermore, Smiths Creek has the same types of subtidal habitats (rocky reef, sandy soft sediments, seagrasses) as do the other 2 creeks.

In each creek, there were 3 locations, one at 'position $1^{\prime}$ at the end of the creek, one at 'position 2' a further $1.5 \mathrm{~km}$ away, and one at 'position 3', which was $3 \mathrm{~km}$ from the end of the creek (Fig. 1). At each location, 2 sites were sampled, one on either side of the creek (i.e. approximately 100 to $150 \mathrm{~m}$ apart). There were 4 aluminium beams per site, each approximately $10 \mathrm{~m}$ apart, and 1 replicate plate was sampled from each beam ( $\mathrm{n}=4$ per site). This sampling regime was determined from studies of natural variability in recruitment of subtidal epibiota (Glasby 1998). In December 1994 (summer 1), 2 plates were attached, one plate distance apart, to each of the 4 beams at every site. One of these

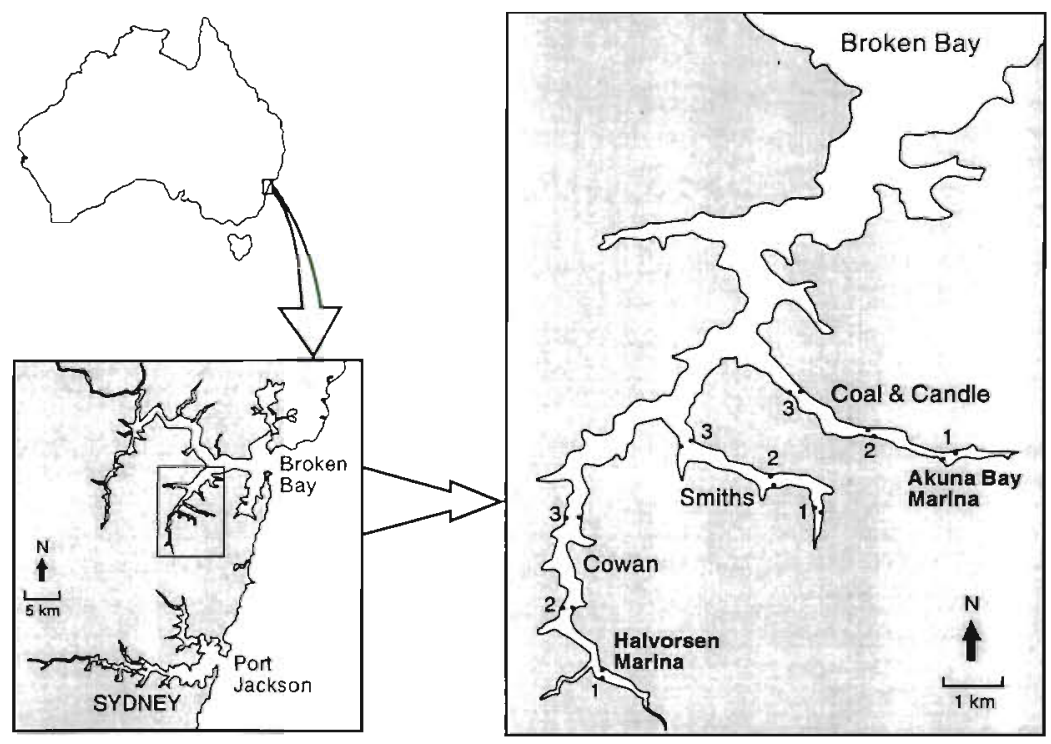

Fig. 1. Study area and the 9 locations in Ku-ring-gai Chase National Park, Australia. There were 3 locations in each creek: 'position 1' at the end of the creek, 'position $2^{\prime}$ in the middle $\left(1.5 \mathrm{~km}\right.$ away) and 'position $3^{\prime}$ at the mouth $(3 \mathrm{~km}$ from the end). There were 2 sites at each location, one on either side of the creek (black dots) plates was collected from each beam after $5 \mathrm{wk}$, the other after $12 \mathrm{wk}$. A second set of plates was deployed in January 1995 (summer 2) in the same manner. Again, 1 set of replicate plates was collected after $5 \mathrm{wk}$ and the other after $12 \mathrm{wk}$.

When the second set of plates was deployed, $25 \times$ $25 \mathrm{~cm}$ areas on vertical faces of rocky reef were cleared next to the plates at 2 locations. The corners of a $15 \times 15 \mathrm{~cm}$ plot within the cleared area were marked with holes and rawl plugs. A visual comparison of the cleared plots and the adjacent plates was made after $12 \mathrm{wk}$. The growth on the plates was very similar to that in the plots and both plates and plots appeared similar to the surrounding rock, except for the lack of macro-algae. Macro-algae were, however, not very abundant on natural rocks and generally only occurred in small clumps (Glasby unpubl.).

Plates were suspended and supported in tubs of seawater for transport back to the lab where they were transferred into filtered $(10 \mu \mathrm{m}$ filter) seawater and refrigerated at $5^{\circ} \mathrm{C}$ until sorted (within $5 \mathrm{~d}$ of collection). Percentage cover of sessile organisms on the fronts of plates was estimated under a stereo-microscope using a grid of 64 regularly spaced points which sampled to within $1 \mathrm{~cm}$ of the edges of the plates (i.e. a $13 \times 13 \mathrm{~cm}$ area) and, thus, avoided 'edge effects'

Replicate measures of physical characteristics of the water at a depth of $1.5 \mathrm{~m}$ were taken on 5 occasions during summer (November to January) at the end of and mid-way along each creek. Mean percentage oxygen saturation ( $\pm \mathrm{SE}$ ) at the ends of Cowan, Smiths and Coal \& Candle creeks were $85.3 \pm 1.9$, $96.0 \pm 1.2$ and $100.6 \pm 1.1$, respectively. Mid-way along the 3 creeks, percentage oxygen saturation was generally greater, i.e. $101.4 \pm 2.7$, $101.1 \pm 1.4$ and $102.5 \pm 1.3$, respectively. Salinity was not significantly different among the positions and was 31.1. Average water temperature was $22.6^{\circ} \mathrm{C}$ and did not differ significantly among positions.

Data were analysed using univariate (ANOVA) and non-parametric multivariate (PRIMER software package; Plymouth Marine Laboratory, UK) techniques. For multivariate analyses, data were double square-root transformed and Bray-Curtis similarity matrices (Bray \& Curtis 1957) were calculated (Clarke \& Green 1988 Clarke 1993). One-way analyses of similarities (ANOSIM; Clarke \& Green 1988) and pairwise comparisons tested for differences in the composi- 
tion of assemblages. If the Bonferroni procedure is used to control the probability of Type I error for multiple pairwise comparisons between groups of 4 replicates (i.e. comparing sites), $\alpha$ becomes unrealistically small $(0.029)$. So, as a compromise, $R$ values (the test statistic used in ANOSIM; Clarke 1993) were compared to help determine which samples were likely to have been significantly different. The greater the value of $R$ (closer to 1 ), the more dissimilar the samples being compared. Only those taxa that were relatively

Table 1. ANOVAs for dominant taxa on plates collected after $5 \mathrm{wk}$. Two sets of plates (summer 1 and summer 2) were sampled 1 mo apart. There was no test for Position except when (1) Site(P) was not significant at $p>0.25$, in which case Position was tested over $\mathrm{C} \times \mathrm{P}$, or a combination of $\mathrm{C} \times \mathrm{P}$ and pooled terms or (2) $\mathrm{C} \times \mathrm{P}$ or both interaction terms were not significant at $\mathrm{p}>0.25$ in which case Position was tested over Site (P). Post-hor pooling was done at $p>0.25$ (see footnote). Data were not transformed except for those taxa marked as being $\ln (x+1)$ transformed. Variances were homogeneous at $p>0.05$ for all tests except for bare space, summer 2, for which variances were homogeneous at $p>0.01$. Creek and Position were random factors. NS: $p>0.05$; ; $<0.05, \cdots p<0.01, \cdots p<0.001$

\begin{tabular}{|c|c|c|c|c|c|c|c|}
\hline \multirow[t]{2}{*}{ Source } & \multirow[t]{2}{*}{ df } & \multicolumn{3}{|c|}{ Summer 1} & \multicolumn{3}{|c|}{ Summer 2} \\
\hline & & MS & F & $\mathrm{p}$ & MS & $F$ & $\mathrm{p}$ \\
\hline (a) Cladophorales & & & & & $\ln (x+1)$ & & \\
\hline Creek & 2 & 9707.17 & 10.80 & $\cdot$ & 16.05 & 6.29 & NS \\
\hline Position & 2 & 818.01 & 0.91 & NS & 0.54 & 0.02 & NS \\
\hline Site $(P)$ & 3 & $92.37^{\mathrm{d}}$ & 0.34 & $>0.25$ & 0.34 & 0.44 & $>0.25$ \\
\hline $\mathrm{C} \times \mathrm{P}$ & 4 & 898.47 & $4.27^{\circ}$ & $\cdot$ & 2.55 & $3.07^{d}$ & $\cdot$ \\
\hline $\mathrm{C} \times \mathrm{S}(\mathrm{P})$ & 6 & $269.37^{\circ}$ & 3.44 & $\cdots$ & $0.76^{\mathrm{d}}$ & 0.91 & $>0.25$ \\
\hline Residual & 54 & 78.40 & & & $0.84^{d}$ & & \\
\hline (b) Feldmania & & $\ln (x+1)$ & & & $\ln (x+1)$ & & \\
\hline Creek & 2 & 11.10 & $12.43^{\mathrm{a}}$ & $\cdots$ & 0.92 & $0.87^{\mathrm{a}}$ & NS \\
\hline Position & 2 & 2.01 & $2.25^{\mathrm{a}}$ & NS & 6.41 & 6.10 & NS \\
\hline Site $(P)$ & 3 & $0.17^{\mathrm{d}}$ & 0.20 & $>0.25$ & 3.56 & 4.02 & NS \\
\hline $\mathrm{C} \times \mathrm{P}$ & 4 & $1.48^{i}$ & 1.72 & $>0.25$ & $1.30^{\mathrm{d}}$ & 1.47 & $>0.25$ \\
\hline$C \times S(P)$ & 6 & $0.86^{\alpha}$ & 1.67 & NS & $0.88^{\mathrm{d}}$ & 1.36 & NS \\
\hline Residual & 54 & 0.52 & & & 0.65 & & \\
\hline (c) Oysters & & & & & $\ln (x+1)$ & & \\
\hline Creek & 2 & 29.70 & 1.55 & NS & 36.83 & 11.45 & $\cdot$ \\
\hline Position & 2 & 1.93 & - & & 0.71 & 0.22 & NS \\
\hline Site $(P)$ & 3 & 10.34 & 1.79 & NS & 0.55 & 0.97 & $>0.25$ \\
\hline $\mathrm{C} \times \mathrm{P}$ & 4 & 19.12 & 3.32 & NS & 3.22 & $5.50^{\circ}$ & $\cdots$ \\
\hline$C \times S(P)$ & 6 & 5.76 & 2.37 & $\cdot$ & $0.57^{\mathrm{d}}$ & 0.97 & $>0.25$ \\
\hline Residual & 54 & 2.43 & & & $0.59^{d}$ & & \\
\hline \multicolumn{8}{|l|}{ (d) Spirorbids } \\
\hline Creek & 2 & 731.30 & 1.47 & NS & 44.66 & 2.18 & NS \\
\hline Position & 2 & 47.71 & - & & 29.70 & - & \\
\hline Site $(P)$ & 3 & 30.18 & $1.40^{\mathrm{a}}$ & NS & 13.94 & 5.71 & $\cdot$ \\
\hline $\mathrm{C} \times \mathrm{P}$ & 4 & 496.88 & $23.10^{\mathrm{a}}$ & $\cdots$ & 20.50 & $5.91^{\prime \prime}$ & $\cdots$ \\
\hline$C \times S(P)$ & 6 & $12.48^{\circ}$ & 0.55 & $>0.25$ & $2.44^{\mathrm{d}}$ & 0.68 & $>0.25$ \\
\hline Residual & 54 & $22.52^{\mathrm{a}}$ & & & $3.58^{\mathrm{d}}$ & & \\
\hline (e) Serpulids & & & & & $\ln (x+1)$ & & \\
\hline Creek & 2 & 23.02 & $12.74^{\mathrm{d}}$ & $\cdots$ & 12.21 & 9.52 & $\cdot$ \\
\hline Position & 2 & 1.05 & 0.58 & NS & 1.14 & - & \\
\hline Site $(P)$ & 3 & 3.97 & $2.19^{a}$ & NS & 1.02 & 3.78 & NS \\
\hline $\mathrm{C} \times \mathrm{P}$ & 4 & $1.61^{\circ}$ & 0.79 & $>0.25$ & 1.28 & 2.50 & NS \\
\hline $\mathrm{C} \times \mathrm{S}(\mathrm{P})$ & 6 & $2.03^{\mathrm{d}}$ & 1.13 & $>0.25$ & $0.27^{\circ}$ & 0.50 & $>0.25$ \\
\hline Residual & 54 & $1.80^{\circ}$ & & & $0.54^{\mathrm{a}}$ & & \\
\hline \multicolumn{8}{|l|}{ (f) Bare space } \\
\hline Creek & 2 & 16842.75 & $60.12^{\mathrm{d}}$ & $\cdots$ & 13125.10 & $51.00^{\mathrm{d}}$ & $\cdots$ \\
\hline Position & 2 & 645.85 & $2.31^{\mathrm{d}}$ & NS & 464.27 & $1.80^{\circ}$ & NS \\
\hline Site $(P)$ & 3 & $159.40^{\text {a }}$ & 0.30 & $>0.25$ & $4.71^{\mathrm{a}}$ & 0.02 & $>0.25$ \\
\hline $\mathrm{C} \times \mathrm{P}$ & 4 & $576.38^{d}$ & 1.10 & $>0.25$ & $378.16^{\mathrm{a}}$ & 1.25 & $>0.25$ \\
\hline $\mathrm{C} \times \mathrm{S}(\mathrm{P})$ & 6 & $523.38^{a}$ & 5.67 & $\cdots$ & $303.07^{a}$ & 1.42 & NS \\
\hline Residual & 54 & 92.36 & & & 213.36 & & \\
\hline
\end{tabular}


abundant (i.e. covering, on average, at least $5 \%$ of the plate) were used in the univariate analyses, whereas all taxa (and 'bare space') were included in the multivariate analyses.

\section{RESULTS}

\section{Samples after 5 weeks}

There were very distinct patterns among locations for each taxon, and for some taxa these patterns differed between the 2 sets of samples (Table 1, Fig. 2). Differences in the percentage cover of taxa occurred among creeks and among positions within a creek (Table 1). Only for bare space were there any significant differences between the 2 sites at a location (summer 1, Fig. $2)$; the significant Creek $\times$ Site(Position) interaction for other taxa occurred because of differences among sites from different locations (Table 1, Fig. 2).

The percentage cover of a number of taxa differed among creeks. The overall covers of green filamentous algae (here grouped as Cladophorales) and brown filamentous algae (represented primarily by the genus Feldmania) were greater in Cowan Creek than in any other creek for the first samples (Table 1a, b, Fig. 2a, b). Furthermore, the cover of green filamentous algae at the marina (position 1) and position 2 in the middle of Cowan Creek was greater than at corresponding positions in the other creeks for the first set of samples, whereas for the second set of samples the cover at position 3 in Cowan Creek was greater than in the other creeks (Table 1a, Fig. 2a). The cover of oysters Saccostrea commercialis in Cowan Creek was greater than in the other 2 creeks for the second set of samples (Table 1c, Fig. 2c), and the cover at the marina in Cowan Creek was greater than at position 1 in Smiths Creek, which was greater than at the marina at Coal \& Candle Creek (Table 1c, Fig. 2c). Note the large difference in cover of oysters between the 2 sets of samples (Fig 2c). Bare space was least common on plates in Cowan Creek for both sets of samples (Fig. 2f, Table 1f).

Similar patterns in the cover of spirorbid polychaetes (species of Neodexiospira, Janua and Pileolaria) occurred for the 2 sets of samples, but far more spirorbids occurred in the summer 1 samples (Fig. 2d). Comparing only the locations at the ends of creeks (position 1), there was a significantly greater percentage cover of spirorbids at Akuna Bay Marina (in Coal \& Candle Creek) than at the other locations (Table 1d, Fig. 2d). The cover of spirorbids at the end (position 3) of Smiths Creek was significantly less than that at position 3 in the other creeks (Table 1d, Fig. 2d). Serpulid polychaetes (species of Hydroides and Spirobranchus) were relatively uncommon and patchily distributed among plates for summer 1, but there were significantly more in Coal \& Candle Creek than in the other 2 creeks (Fig 2e, Table 1e). Serpulids were far more abundant in the second set of samples (Fig. 2e), when percentage covers were greater in Cowan and Coal \& Candle creeks than in Smiths Creek (Table 1e).

Significant differences in the cover of taxa also occurred within creeks. For the first set of samples in Cowan Creek, the cover of green filamentous algae at the marina and $1.5 \mathrm{~km}$ away (position 2) was greater than at position 3 closer to the mouth of the creek (Table 1a, Fig. 2a). Conversely, the cover of spirorbid polychaetes decreased from the marina to position 2 and position 3 along Cowan Creek (Table 1d, Fig. 2d). No differences in the cover of spirorbids occurred among positions in Smiths Creek, but, in Coal \& Candle Creek, the cover of spirorbids at the marina was significantly greater than at the other 2 positions (Table 1d).

Multivariate analyses indicated that, for each set of samples, the sites at most locations were generally not significantly different ( $p>0.05$ ). For both samples, however, the significance level of the comparison between sites at Halvorsen Marina was minimal $(p=0.029$ ). The relatively large $R$ value for the comparison for the first set of samples $(R=0.604)$ suggests that the sites may in fact have been different, but this may not have been the case for the second set of samples $(R=0.281)$. Despite the possible difference between sites at Halvorsen's, comparisons were made between all locations by pooling replicates between sites (so that $\mathbf{n}=8$ at each location). ANOSIM indicated that, for the first set of samples, all 3 positions in Cowan Creek were different from each other (Table 2, Fig. 3) and different from the positions in Smiths and Coal \& Candle creeks (Table 3, Fig. 3). For the second set of samples, position 1 in Cowan Creek was significantly different from positions 2 and 3 (Table 2, Fig. 3), and again all 3 positions in Cowan were different from positions in other creeks (Table 3, Fig. 3). The composition of assemblages at all 3 positions within Smiths Creek were similar to each other and the same pattern occurred among positions in Coal \& Candle Creek (Table 2, Fig. 3). All 3 locations at the end of the creeks (position 1) were, however, significantly different (Fig. 3a, b, Table 3).

\section{Samples after 12 weeks}

As for samples after $5 \mathrm{wk}$, differences in the cover of taxa occurred among creeks and among positions within creeks after 12 wk (Table 4, Fig. 4). Abundances of most taxa were very different by this later stage, but 

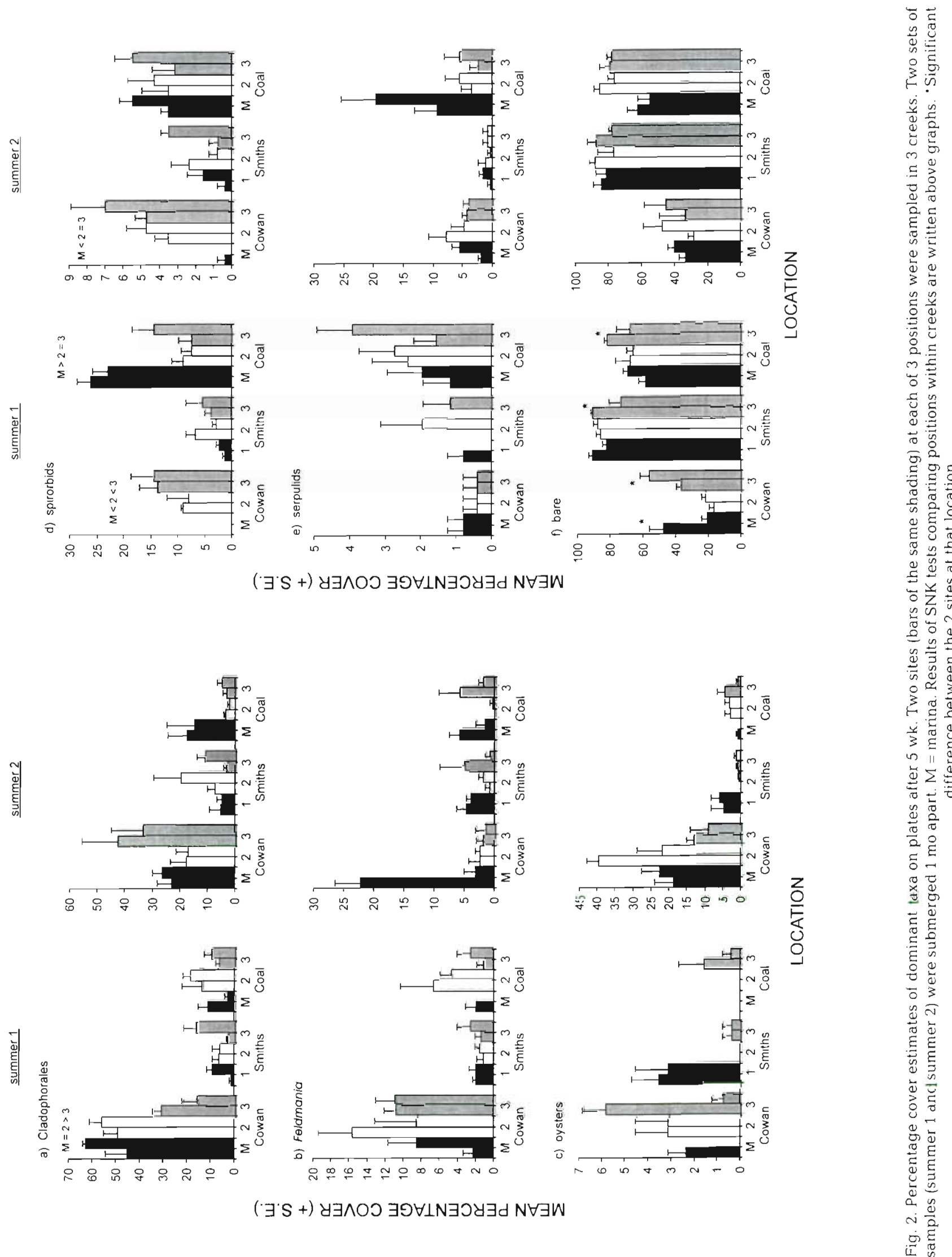

$(\cdot \exists \cdot S+)$ y $\exists \wedge O \supset \exists \supset \forall \perp N \exists \supset y \exists d N \forall \exists W$ 
Table 2. $R$ values from multivariate pairwise comparisons of assemblages between positions within the same creek. Two independent sets of samples each were taken after $5 \mathrm{wk}$ and $12 \mathrm{wk}$. There were 3 positions (1: end, 2: middle, $1.5 \mathrm{~km}$ from end and 3: mouth, $3 \mathrm{~km}$ from end) in each creek; the marinas (M) were at 'position 1 ' in Cowan and Coal \& Candle creeks. Significant differences are marked ("), but different levels of significance are not distinguished

\begin{tabular}{|c|c|c|c|c|c|}
\hline \multirow[t]{2}{*}{ Creek } & \multirow[t]{2}{*}{ Comparison } & \multicolumn{2}{|c|}{5 weeks } & \multicolumn{2}{|c|}{12 weeks } \\
\hline & & Summer 1 & Summer 2 & Summer 1 & Summer 2 \\
\hline \multirow[t]{3}{*}{ Cowan } & M vs 2 & $0.480^{\circ}$ & $0.426^{\circ}$ & $0.535^{\bullet}$ & $0.539^{\circ}$ \\
\hline & 2 vs 3 & $0.419^{\circ}$ & 0.141 & -0.008 & 0.001 \\
\hline & Mvs 3 & $0.739^{\circ}$ & $0.532^{\circ}$ & $0.529^{\circ}$ & $0.651^{\circ}$ \\
\hline \multirow[t]{3}{*}{ Smiths } & 1 vs 2 & 0.249 & 0.102 & $0.579^{\circ}$ & $0.323^{\circ}$ \\
\hline & 2 vs 3 & -0.060 & 0.096 & -0.009 & $0.431^{\circ}$ \\
\hline & 1 vs 3 & 0.008 & 0.235 & $0.876^{\circ}$ & $0.532^{\circ}$ \\
\hline \multirow[t]{3}{*}{ Coal \& Candle } & M vs 2 & 0.265 & 0.313 & 0.123 & -0.110 \\
\hline & 2 vs 3 & 0.065 & 0.066 & -0.001 & -0.068 \\
\hline & M vs 3 & 0.201 & 0.136 & 0.161 & -0.021 \\
\hline
\end{tabular}

Table 3. $R$ values from multivariate pairwise comparisons of assemblages between positions in different creeks. Significant differences are marked ("), but different levels of significance are not distinguished

\begin{tabular}{|c|c|c|c|c|c|}
\hline \multirow[t]{2}{*}{ Position } & \multirow[t]{2}{*}{ Comparison } & \multicolumn{2}{|c|}{5 weeks } & \multicolumn{2}{|c|}{12 weeks } \\
\hline & & Summer 1 & Summer 2 & Summer 1 & Summer 2 \\
\hline \multirow[t]{3}{*}{1} & Cowan vs Smiths & $0.702^{\circ}$ & $0.400^{\circ}$ & $0.425^{\circ}$ & $0.558^{\circ}$ \\
\hline & Smiths vs Coal & $0.652^{\circ}$ & $0.379^{\circ}$ & $0.811^{\circ}$ & $0.484^{\circ}$ \\
\hline & Cowan vs Coal & $0.946^{\circ}$ & $0.667^{\circ}$ & $0.802^{\circ}$ & $0.749^{\circ}$ \\
\hline \multirow[t]{3}{*}{2} & Cowan vs Smiths & $0.863^{\circ}$ & $0.677^{\circ}$ & $0.642^{\circ}$ & $0.403^{\circ}$ \\
\hline & Smiths vs Coal & 0.249 & 0.331 & 0.162 & $0.436^{\circ}$ \\
\hline & Cowan vs Coal & $0.810^{\circ}$ & $0.501^{\circ}$ & $0.855^{\circ}$ & 0.271 \\
\hline \multirow[t]{3}{*}{3} & Cowan vs Smiths & $0.332^{\circ}$ & $0.683^{\circ}$ & $0.876^{\circ}$ & 0.200 \\
\hline & Smiths vs Coal & 0.090 & 0.075 & 0.115 & 0.155 \\
\hline & Cowan vs Coal & $0.539^{\circ}$ & $0.480^{\circ}$ & $0.826^{\circ}$ & $0.257^{\circ}$ \\
\hline
\end{tabular}

there were, nevertheless, similar patterns among locations for certain taxa (Figs. $2 \& 4$ ). Differences between sites were uncommon and occurred only at some locations for serpulid polychaetes and green and brown filamentous algae (Fig. 4).

The percentage cover of green filamentous algae (Cladophorales) was significantly greater in Cowan Creek for the first set of samples (Fig. 4a, Table 4a). For the second samples, the cover in Cowan was not different from that in Smiths and was significantly greater than that in Coal \& Candle Creek (Fig. 4a, Table 4a). There was a similar trend for the cover of the brown filamentous alga Feldmania sp. to decrease from Cowan Creek to Coal \& Candle Creek (i.e. moving seawards, Fig. 4b). The cover of oysters at the marina in Coal \& Candle Creek was significantly less than at the ends of the other 2 creeks (Table $3 \mathrm{~d}$ ). Furthermore, there were significantly more oysters in the middle (position 2) and mouth (position 3) of Cowan Creek than at corresponding positions in Smiths and Coal \& Candle creeks. None of these differences was apparent in the second set of samples (Fig. 4c, Table 4c).
There tended to be far more spirorbid polychaetes at position 1 in Coal \& Candle Creek (Akuna Bay Marina) than at position 1 in the other 2 creeks (Fig. 4 d). Serpulid polychaetes were significantly more abundant in Coal \&
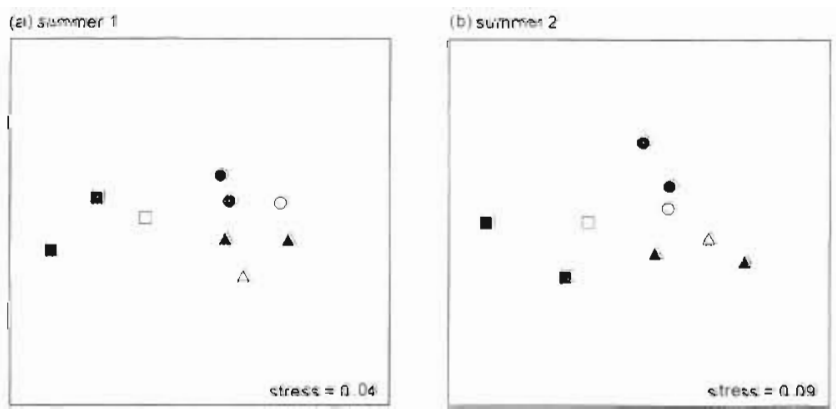

Fig. 3. nMDS ordinations for the 2 sets of 5 wk samples (see Fig. 2), comparing the composition of assemblages at 3 positions (1: black, 2: grey, 3: white) within 3 creeks: Cowan (squares), Smiths (circles) and Coal \& Candle (triangles). The 2 marinas are the black square and the black triangle 
Table 4. ANOVA for dominant taxa on plates collected after $12 \mathrm{wk}$. Two sets of plates (summer 1 and summer 2) were sampled 1 mo apart. See Table 1 for detals of tests. Variances were homogeneous at $p>0.05$ for all tests. NS: $p>0.05, \cdot p<0.05$, $\cdots p<0.01, \cdots p<0.001$

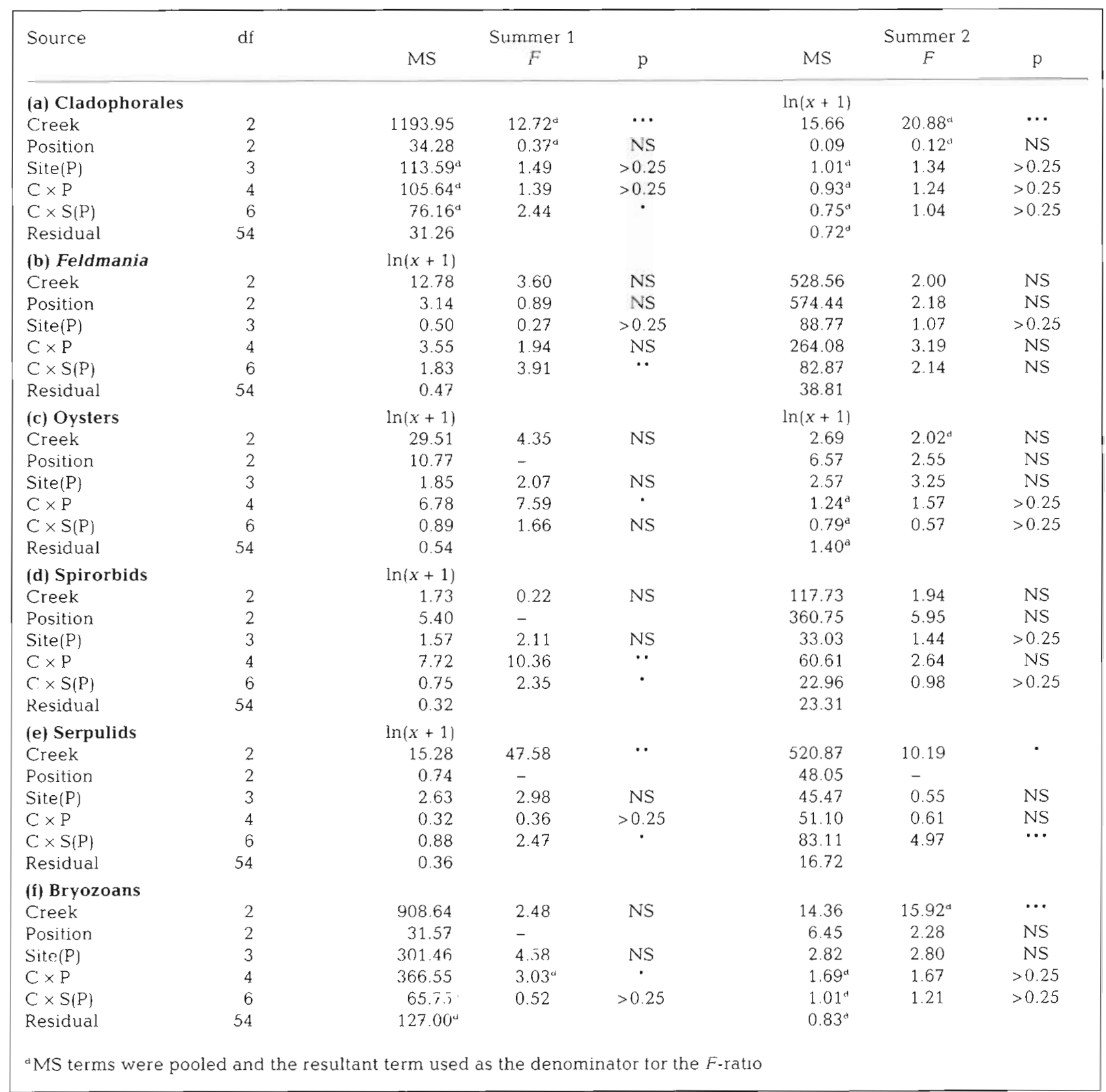

Candle Creek than in the other creeks (Table 4e). Similarly, the percentage cover of encrusting bryozoans tended to increase from Cowan Creek to Coal \& Candle Creek, and there were significant differences among all 3 creeks for the second set of samples (Fig. 4f, Table 4f). For the summer 1 samples, there was a significantly smaller percentage cover of bryozoans in the middle of Cowan Creek compared to the corresponding positions in Smiths and Coal \& Candle creeks (Table 4f).
Differences occurred among positions within creeks for only a few taxa. There was a trend for the cover of green filamentous (Cladophorales) and brown filamentous (Feldmania sp.) algae to increase towards the end (position 1) of Smiths Creek for the summer 1 samples (Fig. 4a, b). A similar pattern occurred for oysters within Smiths Creek. For the first set of samples, the percentage cover of oysters at the end of Smiths Creek was significantly greater than that at the other 2 posi- 

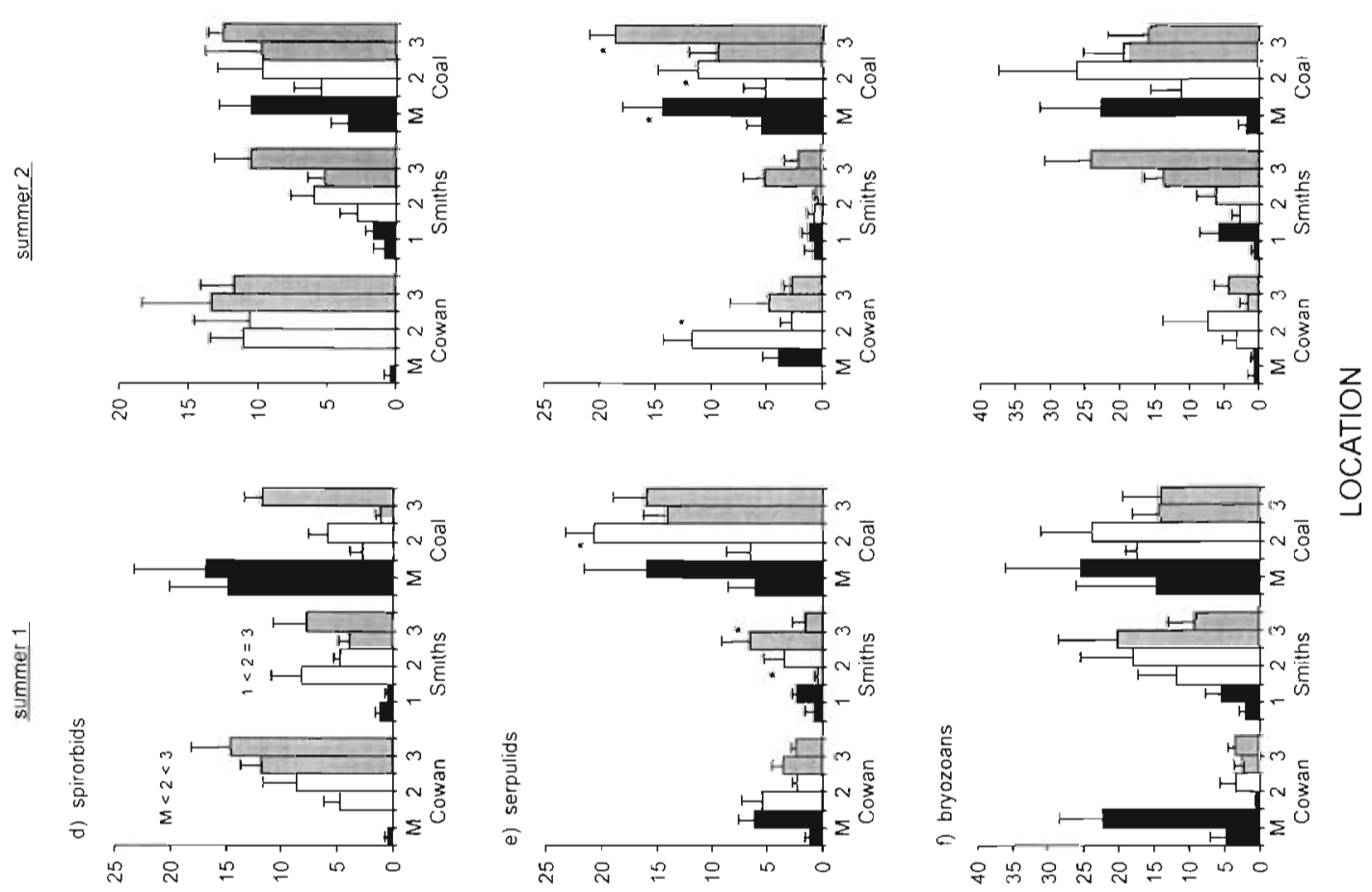

$(\exists \cdot S+)$ y $\exists \wedge O \supset \exists O \forall \perp N \exists J y \exists d N \forall \exists W$
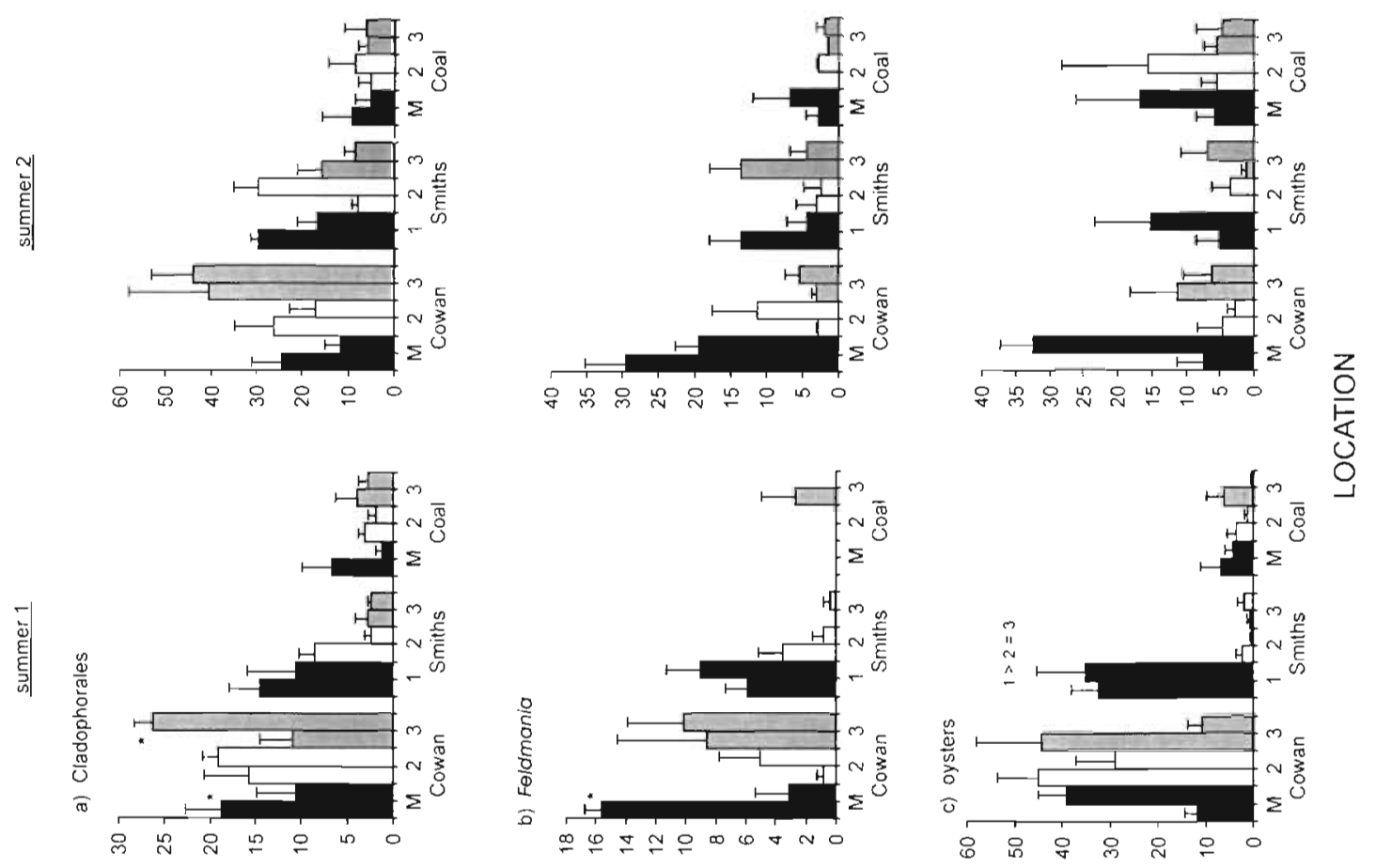

$(\cdot \exists S+) y \exists \wedge O \supset \exists \supset \forall \perp N \exists \supset \forall \exists d N \forall \exists W$

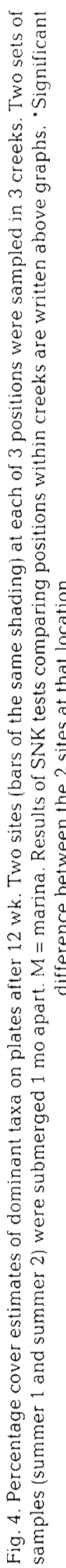


(a) summer 1
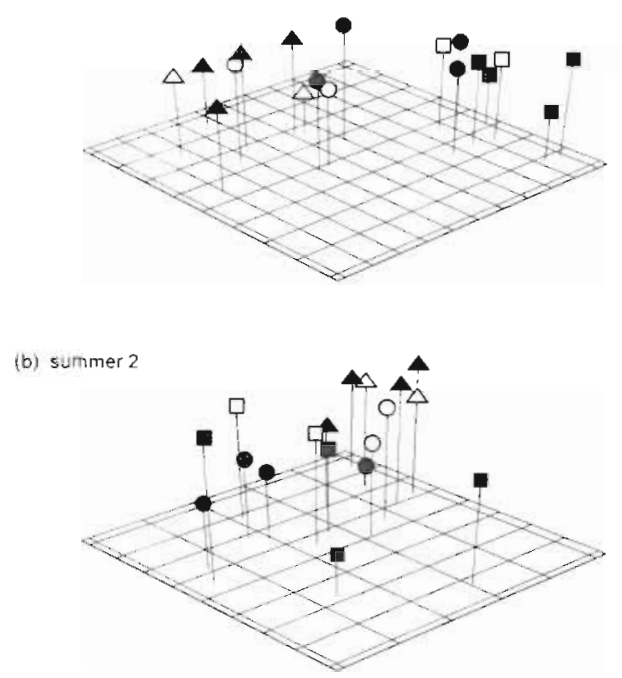

Fig. 5. Three-dimensional nMDS ordinations for the 2 sets of 12 wk samples (see Fig. 4), comparing the composition of assemblages at 2 sites (duplicated symbols) within locations in 3 creeks: Cowan (squares), Smiths (circles) and Coal \& Candle (triangles). The differently shaded symbols represent the 3 positions in each creek: position 1 (black), position 2 (grey) and position 3 (white). The 2 marinas on the black squares and the black triangles. Stress values are (a) 0.06 , (b) 0.07

tions (Table 4c, Fig. 4c). Spirorbid polychaetes were significantly less abundant at the end of Cowan and Smiths creeks than at the other 2 positions within the creeks for the summer 1 samples (Table $4 \mathrm{~d}$, Fig. $4 \mathrm{~d}$ ). The same pattern occurred for the summer 2 samples, but the difference was not significant (Table $4 \mathrm{~d}$, Fig. 4d).

Multivariate analyses indicated that there were quite probably differences among sites at some locations (i.e. $\mathrm{p}=0.029$ ). The greatest $R$ values for the comparison between sites occurred at the 2 marina locations. Furthermore, the only difference between sites that may have occurred at both times of sampling was at Halvorsen Marina (position 1 in Cowan Creek) and this is clearly shown by the nMDS ordinations (Fig 5). Ordinations were presented as 3-dimensional plots to provide the most accurate representation of all the sites. ANOSIM demonstrated that, for both samples, the assemblages at position 1 in Cowan Creek were quite unlike those at any other position (Tables $2 \& 3$ ). Moreover, locations at the ends of the 3 creeks were all dissimilar at each time of sampling (Table 3). Other patterns differed slightly between samples. For the summer 1 samples, the composition of assemblages at the end of Smiths Creek (position 1) was unlike that at the other 2 positions in the creek (Table 2). Whereas in Coal \& Candle Creek, all 3 positions were similar to each other (Table 2) and similar to positions 2 and 3 in Smiths Creek. Likewise, the summer 2 samples from Coal \& Candle Creek were all similar to each other (Table 2) and not different from those in position 3 in Smiths Creek (Table 3). All 3 of the positions in Smiths Creek were, however, different from each other in the second set of samples (Table 2).

Using the results of multivariate comparisons among assemblages at different positions within creeks ( $R$ values in Table 3), 2-factor ANOVAs were constructed to compare the dissimilarity between positions for each creek for the $5 \mathrm{wk}$ and $12 \mathrm{wk}$ samples. If marinas had effects that extended to $1.5 \mathrm{~km}$, the dissimilarity between assemblages at positions 1 and 2 in the creeks containing marinas should be less than that between the corresponding positions in the control (Smiths) creek. The results showed that there were no differences in the patterns among positions in the marina and control creeks (i.e. no $\mathrm{C} \times \mathrm{P}$ interaction) and, therefore, no indication that the marinas were having any effects on assemblages $1.5 \mathrm{~km}$ away (Table 5).

\section{DISCUSSION}

Patterns among locations were generally similar for the 2 sets of samples, although for some taxa there were large differences in percentage covers between

Table 5. ANOVAs comparing the dissimilarity between positions 1 (end), 2 (middle, $1.5 \mathrm{~km}$ from end) and 3 ( $3 \mathrm{~km}$ from end) in each of 3 creeks (Cowan, Smiths, Coal \& Candle). Data used are $R$ values from multivariate comparisons of the assesmblages among positions within each creek (see Table 3) for 2 sets of samples after $5 \mathrm{wk}$ and $12 \mathrm{wk} ; \mathrm{n}=2$. The test for overall differences among creeks was irrelevant to our hypotheses. Data were untransformed and variances were homogeneous. NS: not significant

\begin{tabular}{|c|c|c|c|c|c|c|c|}
\hline \multirow[t]{2}{*}{ Source } & \multirow[t]{2}{*}{ df } & \multicolumn{3}{|c|}{5 weeks } & \multicolumn{3}{|c|}{12 weeks } \\
\hline & & MS & $F$ & $p$ & MS & $F$ & $p$ \\
\hline Creek & 2 & 0.206 & 1.6 .04 & - & 0.332 & 1.2 .28 & - \\
\hline Position & 2 & 0.069 & 4.46 & NS & 0.248 & 5.21 & NS \\
\hline$C \times P$ & 4 & 0.015 & 1.20 & NS & 0.048 & 1.76 & NS \\
\hline Residual & 9 & 0.013 & & & 0.027 & & \\
\hline
\end{tabular}


samples. Spirorbids, serpulids and oysters were common on plates in only 1 set of samples after $5 \mathrm{wk}$, but, by $12 \mathrm{wk}$, the percentage covers of these taxa were similar for the 2 sets of samples. Thus, recruitment of these taxa occurred at different stages of development of the assemblages for the 2 sets of samples. Percentage covers of green and brown filamentous algae (Cladophorales and Feldmania sp.) differed consistently between sets of samples. These discrepancies between samples resulted in less bare space on many plates for the second set of samples after $12 \mathrm{wk}$. Thus, over a period of $12 \mathrm{wk}$, the composition of assemblages on the plates differed according to the week that the plates were put into the water. This supports previous findings that the development of epibiotic assemblages can differ considerably within as well as among seasons (e.g. Keough 1983, Anderson \& Underwood 1994). It is not clear whether differences that occur over short time periods may be maintained for longer periods (Greene \& Schoener 1982, Anderson \& Underwood 1994), but there is substantial evidence that established organisms can influence subsequent colonization (see review by Downes \& Keough 1998).

\section{Spatial extent of the effects of marinas}

Large differences in the cover of many taxa occurred between the 2 marinas. Clearly, if the marinas are having any effects on the establishment of epibiota, they are not the same at the 2 locations. Few previous studies have compared multiple marinas, but those that have also identified significant differences in the cover and biomass of certain sessile organisms among marinas (Lenihan et al. 1990, Van Dolah et al. 1992, Glasby 1997, Turner et al. 1997). Patterns in the percentage cover of spirorbid and serpulid polychaetes within Coal \& Candle Creek were clearly different from those in the other 2 creeks. Polychaetes were generally uncommon on plates at the ends of creeks, but at Akuna Bay Marina they were very abundant. This suggests that the marina may somehow enhance the local abundance/settlement of tubiculous polychaetes, a result consistent with the findings of Lenihan et al. (1990).

The great variability among positions within creeks makes it difficult to determine whether the marinas are having effects which extend along the creeks. We hypothesised that large-scale $(>1.5 \mathrm{~km})$ effects of marinas would be implied if recruitment at the marinas was similar to that at other positions within the creeks and different from that in the control creek. The only univariate result indicative of a large-scale effect was for Cladophorales in the first $5 \mathrm{wk}$ sample. The percentage cover of these green algae in Cowan Creek was significantly greater at Halvorsen Marina (position 1) and position 2 than at position 3 . This result was, however, not consistent and, in fact, for the second set of samples the opposite pattern occurred.

Multivariate analyses did not indicate that Halvorsen Marina had any large-scale effect on the composition of newly developed assemblages. Assemblages at the marina were always different from those at other positions within Cowan Creek. The pattern within Coal \& Candle Creek (containing Akuna Bay Marina) was, however, different in that the composition of assemblages at all 3 positions was always similar. This result, on its own, could suggest that the marina affected the entire creek. There were, however, rarely any significant differences between positions 2 and 3 in Coal \& Candle Creek and the corresponding positions in the control creek (Smiths Creek). Furthermore, position 1 at the end of Smiths Creek was different from the other positions in the creek for the $12 \mathrm{wk}$ samples and different from Akuna Bay Marina. Thus, it is perhaps more likely that Akuna Bay Marina either had only a localized effect or did not have any effect on the composition of the subtidal assemblages of epibiota. This conclusion is supported by the comparison of dissimilarities between assemblages in different positions within the creeks (Table 5). The patterns among positions were similar for each of the 3 creeks. Thus, there was no suggestion that the marinas were affecting assemblages $1.5 \mathrm{~km}$ or $3 \mathrm{~km}$ away.

The composition of assemblages at Halvorsen Marina was very different from all other locations. This may be a consequence of the marina (which has been in operation for $50 \mathrm{yr}$ ) or may be because the location is at the end of the entire estuary and therefore different from other locations. The end of Smiths Creek is ostensibly very similar to the end of Cowan Creek, but movement of water, tidal flushing, input of fresh water, etc. could still differ between the 2 locations. Certainly there were differences in concentrations of dissolved oxygen (see 'Materials and methods'). Abiotic differences, together with natural patchiness in recruitment, could quite conceivably explain the observed differences in assemblages among locations. Large spatial variability has been documented in many studies of subtidal epibiota (e.g. Kay \& Keough 1981, Butler 1986, Kennelly \& Underwood 1992, Glasby 1998), but this is often not estimated in environmental studies.

\section{Natural differences within creeks}

Natural differences in recruitment and the development of sessile assemblages occurred along the creeks. There was often a gradient from the end to the mouth of Smiths Creek in the percentage cover of taxa. 
Spirorbids and bryozoans tended to be less common at the end of the creek (position 1) and their percentage covers increased towards the mouth. Conversely, the percentage cover of oysters was often greater at the end than at the other 2 positions in Smiths Creek. Furthermore, green and brown filamentous algae (Cladophorales and Feldmania sp.) tended to be most common at the end of this creek.

Multivariate analyses indicated that, after $12 \mathrm{wk}$, assemblages at the end of Smiths Creek were significantly different from those at the other 2 positions. This was not due to certain taxa being absent from the end of the creek, but, rather, because different taxa dominated assemblages at this position. This suggests that conditions at the end of the creek may be different from those near the mouth and that the dominant taxa may either recruit in greater densities or be better able to survive and grow in the conditions at the end of the creek.

\section{Considerations for environmental studies of estuarine epibiota}

This study has highlighted the importance of largescale variability (over 1000 s of metres) in epíbiotic assemblages. Significant differences occurred among newly developed assemblages of epibiota at control locations that appeared to be very similar. Many of these differences were correlated with natural gradients within creeks. This has important ramifications for selecting control locations. Unless controls were in positions within creeks that corresponded to the position of a marina, it is likely that an impact could either be detected erroneously or masked (because different habitats were actually being sampled, see Morrisey \& Underwood 1992, Morrisey et al. 1992). Moreover, multiple control locations will obviously be necessary in order to obtain an accurate estimate of the composition of 'natural' assemblages of epibiota at undisturbed locations (Underwood 1989, 1992).

Unfortunately, most studies of marinas have forgone detailed investigations of natural variation and it is rare for sufficient justification to be given for the choice of control locations (e.g. Baird et al. 1981, Voudrias \& Smith 1986, Lenihan et al. 1990, Wendt et al. 1990, Van Dolah et al. 1992, McGee et al. 1995, Turner et al. 1997). The specific criteria used for the selection of control locations must be given for any environmental study (e.g. Kennicutt et al. 1996) in addition to full details about the locations used. Our results demonstrate how seemingly appropriate control locations may, in fact, be totally inadequate because of environmental variables that were not considered because there was no prior reason to include them.
The choice of control locations will be particularly important for any 'post-impact' study (i.e. when no data are available from before the disturbance) because the detection of an impact often relies on spatial differences between the putatively impacted location and the controls (Underwood 1992, Peterson 1993, Glasby 1997, Keough \& Mapstone 1997). Thus, it is surprising that detailed descriptions of control locations are rarely presented as part of investigations of environmental impacts. Most ecologists accept the need for control locations, but it seems adequate merely to state that controls were used and present a map showing their positions. To anybody who is not extremely familiar with the study area, such non-specific information is of little use for assessing the validity of the study. The rationale for choosing controls is as important as any other aspect of an environmental study.

This leads to the question of how controls should be selected. Some of the common (and fairly non-specific) considerations for choosing control locations were outlined in the 'Introduction'. Results from this study have indicated that certain physical factors may play a very important part in determining the composition of assemblages of epibiota. Clearly, therefore, these factors need to be identified and accounted for when choosing control locations for post-impact studies. In essence, this means trying to identify the factors that most determine natural variability among seemingly similar locations (Underwood 1994). Certainly this is no easy task, but we suggest that it will become increasingly necessary to enable comprehensive tests for environmental impacts when no 'before' data are available. Data collected from investigations of natural variability could also provide important baseline data (i.e. 'before' data) if done in habitats that were often subjected to anthropogenic disturbances (Lewis 1976 . Hilborn \& Walters 1981, Fairweather 1993, Underwood 1994).

Acknowledgements. The production of this paper was assisted by an Australian Postgraduate Award, funds from the Institute of Marine Ecology and, during preparation of the manuscript, the Centre for Research on Ecological Impacts of Coastal Cities (University of Sydney). We thank V. Mathews, M. Beck, T Crowe, M. Haddon, A. Jinks, S. McCune and W. McBeth for assistance in the field. Drs G. Rouse and D. Gordon and Prof. A. W. Larkum helped identify specimens. Sandstone was provided by Gosford Quarries Pty Ltd. Previous versions of the manuscript benefited from comments by $A$. J. Butler, T. P. Crowe, J. S. Gray, S. J. Hawkins, M. J. Kaiser and C. D. Todd.

\section{LITERATURE CITED}

Anderson MJ, Underwood AJ (1994) Effects of substratum on the recruitment and development of an intertidal estuarine fouling assemblage. J Exp Mar Biol Ecol 184:217-236 
Andrew NL, Mapstone BD (1987) Sampling and the description of spatial pattern in marne ecology. Annu Rev Oceanogr Mar Biol 25:39-90

Baird D, Marais JFK, Wooldridge T (1981) The influence of a marina canal system on the ecology of the Kromme estuary, St. Francis Bay. S Afr J Zool 16:21-34

Barnes RSK (1984) Estuarine Biology, 2nd edn. Edward Arnold Ltd, London

Barnes RSK. Hughes RN (1990) An introduction to marine ecology (2nd edn). Blackwell Scientific Publications, Oxford

Batley GE, Mann KJ, Brickbank CI, Maltz A (1989) Tributyltın in Sydney Harbour and Georges River waters. Aust J Mar Freshwat Res 40:39-48

Bayne BL, Clarke KR, Gray JS (eds) (1988) Biological effects of pollutants: results of a practical workshop. Mar Ecol Prog Ser 46

Bender EA, Case TJ, Gilpin ME (1984) Perturbation experiments in community ecology: theory and practice. Ecology 65:1-13

Bray JR, Curtis JT (1957) An ordination of the upland forest communities of Southern Wisconsin. Ecol Monogr 27 $325-349$

Butler AJ (1986) Recruitment of sessile invertebrates at five sites in Gulf St. Vincent, South Australia. J Exp Mar Biol Ecol 97:13-36

Clarke KR (1993) Non-parametric multivariate analyses of changes in community structure. Aust J Ecol 18:117-143

Clarke KR, Green RH (1988) Statistical design and analysis for a 'biological effects' study. Mar Ecol Prog Ser 46 $213-226$

Cosser PR (1989) Water quality, sediments and the macroinvertebrate community of residential canal estates in southeast Queensland, Australia: a multivariate analysis. Wat Res 23:1087-1097

Downes BJ, Keough MJ (1998) Scaling of colonization processes in streams: parallels and lessons from marine hard substrata. Aust J Ecol 23:8-26

Fairweather PG (1993) Links between ecology and ecophilosophy, ethics and the requirements of environmental management. Aust J Ecol 18:3-19

Glasby TM (1997) Analysing data from post-impact studies using asymmetrical analyses of variance: a case study of epibiota on marinas. Aust $\mathrm{J}$ Ecol 22:448-459

Glasby TM (1998) Estimating spatial variability in developing assemblages of epibiota on subtidal hard substrata. Mar Freshwat Res (in press)

Glasby TM, Underwood AJ (1996) Sampling to differentiate between pulse and press perturbations. Environ Monit Assess 42:241-252

Green RH (1979) Sampling design and statistical methods for environmental biologists. Wiley Interscience, Chichester

Greene $\mathrm{CH}$, Schoener A (1982) Succession on marine hard substrata: a fixed lottery. Oecologia 55:289-297

Hasan MA, Juma HA (1992) Assessment of tributyltin in the marine environment of Bahrain. Mar Pollut Bull 24: $408-410$

Hilborn R, Walters CJ (1981) Pitfalls of environmental baseline and process studies. ElA Review 2:265-278

Kay AM, Keough MJ (1981) Occupation of patches in the epifaunal communities on pier pilings and the bivalve Pinna bicolour at Edithburgh, South Australia. Oecologia 48: $123-130$

Kennelly SJ, Underwood AJ (1992) Fluctuations in the distribution and abundance of species in sublittoral kelp forests in Vew South Wales. Aust J Ecol 17:367-382

Kennicutt MC, Green RH, Montagna P, Roscigno PF (1996)
Gulf of Mexico offshore operations monitoring experiment (GOOMEX), phase I: sublethal responses to contaminant exposure-introduction and overview. Can J Fish Aquat Sci 53:2540-2553

Keough MJ (1983) Patterns of recruitment of sessile invertebrates in two subtidal habitats. J Exp Mar Biol Ecol 66: $213-245$

Keough MJ, Mapstone BD (1997) Designing environmental monitoring for pulp mills in Australia. Wat Sci Tech 35 $397-404$

Ko MMC, Bradley GC, Neller AH, Broom MJ (1995) Tributyltin contamination of marine sediments of Hong Kong Mar Pollut Bull 31:249-253

Le Bris H, Glémarec M (1996) Marine and brackish ecosystems of South Brittany (Lonent and Vilaine Bays) with particular reference to the effect of the turbidity maxima Estuar Coast Shelf Sci 42:737-753

Lenihan HS, Oliver JS, Stephenson MA (1990) Changes in hard bottom communities related to boat mooring and tributyltin in San Diego Bay: a natural experiment. Mar Ecol Prog Ser 60:147-159

Lewis JR (1976) Long-term ecological surveillance: practical realities in the rocky littoral. Annu Rev Oceanogr Mar Biol 14:371-390

McGee BL, Schlekat CE, Boward DM, Wade TL (1995) Sediment contamination and biological effects in a Chesapeake Bay marina. Ecoloxicology 4:39-59

Morrisey DJ, Howitt L, Underwood AJ, Stark JS (1992) Spatial variation in soft-sediment benthos. Mar Ecol Prog Ser 81. $197-204$

Morrisey DJ, Underwood AJ (1992) Sampling for spatial variation in the distribution of fauna in sediments. In: Misckiewicz AG (ed) Proceedings of a bioaccumulation workshop: assessment of the distribution, impacts and bioaccumulation of contaminants in aquatic environments. Water Board and Australian Marine Sciences Association, Sydney, p 108-114

Parsons TR, Takahashi M, Hargrave B (1990) Biological oceanographic processes. Pergamon Press, Oxford

Peterson CH. (1993) Improvement of environmental impact analysis by application of principles derived from manipulative ecology: lessons from coastal marine case histories. Aust J Ecol 18:21-52

Stewart-Oaten A (1996) Problems in the analysis of environmental monitoring data. In: Schmitt RJ, Osenberg CW (eds) Detecting ecological impacts: concepts and applications in coastal habitats. Academic Press, San Diego, p 109-131

Turner SJ, Thrush SF, Cummings VJ, Hewitt JE, Wilkinson MR, Willamson RB, Lee DJ (1997) Changes in eplfaunal assemblages in response to marina operations and boating activities Mar Environ Res 43:181-199

Underwood AJ (1981) Techniques of analysis of variance in experumental marine biology and ecology. Annu Rev Oceanogr Mar Biol 19:513-605

Underwood AJ (1989) The analysis of stress in natural populations. Biol J Linn Soc 37:51-78

Underwood AJ (1992) Beyond BACI: the detection of environmental impact on populations in the real, but variable. world. J Exp Mar Biol Ecol 161:145-178

Underwood AJ (1994) On beyond BACI sampling designs that might reliably detect environmental disturbances. Ecol Appl 4:3-15

Van Dolah RF, Bobo MY, Levisen MV, Wendt PH, Manzi JJ (1992) Effects of marina proximity on the physiological condition, reproduction, and settlement of oyster populatıons. J Shellfish Res 11:41-48 
Voudrias EA, Smith CL (1986) Hydrocarbon pollution from marinas in estuarine sediments. Estuar Coast Shelf Sci 22: $271-284$

Wendt PH, Van Dolah RF, Bobo MY, Manzi JJ (1990) Effects of marina proximity on certain aspects of the biology of oysters and other benthic macrofauna in a South Carolina

Editorial responsibility: Roger Hughes (Contributing Editor), Bangor, Gwynedd, UK estuary. South Carolina Marine Resources Center, Tech Rep No. 74. South Carolina Wildlife and Marine Resources Department, Charleston

Wiens JA, Parker KR (1995) Analyzing the effects of accidental environmental impacts: approaches and assumptions. Ecol Appl 5:1069-1083

Submitted: March 26, 1998; Accepted: July 3, 1998 Proofs received from author(s): September 7, 1998 